\title{
TECHNOLOGIE DESKOWAŃ TRACONYCH STOSOWANE W RAMACH TECHNOLOGII BUDOWNICTWA MONOLITYCZNEGO
}

\begin{abstract}
Streszczenie: Deskowania budowlane są niezbędnym elementem koniecznym do realizacji konstrukcji betonowych czy też żelbetowych wykonanych $w$ technologii budownictwa monolitycznego. Jednym z przykładów są deskowania tracone, które zyskują na znaczeniu z uwagi na bardzo dużą różnorodność konstrukcyjną, technologiczną oraz materiałową. W rozdziale przedstawiono charakterystykę i zakres zastosowania deskowań traconych oraz zaprezentowano ich klasyfikację wraz z kryteriami podziału. Omówione zostały również wybrane systemy deskowań traconych, w tym technologie umożliwiające zastosowanie materiałów kompozytowych jako alternatywę dla tradycyjnych deskowań budowlanych.
\end{abstract}

Słowa kluczowe: deskowania budowlane, deskowania tracone, urządzenia formujące, monolityczne konstrukcje betonowe, kompozyty.

\section{Wprowadzenie}

Szacuje się, że konstrukcje budowlane wykonane w technologii betonu stanowią około 60-70\% realizowanych obiektów budowlanych i inżynierskich (IGNATOWsKi P. 2008). Niemal wszystkie wznoszone konstrukcje budowlane i inżynierskie, takie jak podpory mostowe (filary czy przyczółki), tunele, budynki wysokie czy obiekty hydrotechniczne, w tym konstrukcje morskie, wykonywane są w technologii betonu monolitycznego, głownie jako konstrukcje żelbetowe. Powszechność tej technologii wynika zasadniczo z kilku szczególnych cech jakimi są: dowolność kształtowania formy architektonicznej, bardzo wysoka trwałość konstruowanych elementów, możliwość stosowania korzystnych układów statycznych, a także zwiększona odporność obiektów narażonych na oddziaływania dynamiczne czy nawet sejsmiczne (ORŁOWSKI Z. 2013).

Niemal każda konstrukcja realizowana w technologii betonu monolitycznego wykonywana jest bezpośrednio na placu budowy, co oznacza konieczność zastosowania specjalnych urządzeń formujących, potocznie nazywanych

mgr inż., Wydział Budownictwa Politechniki Częstochowskiej, e-mail: kbrozda@bud.pcz.czest.pl

dr hab. inż., prof. PCz, Wydział Budownictwa Politechniki Częstochowskiej, e-mail:

jaceksel@poczta.onet.pl 
deskowaniem, do ukształtowania poszczególnych elementów betonowych (JASICZAK J. 2003). Współczesne rozwiązania deskowań budowlanych według polskiej normy (PN-M-47850:1990), wycofanej bez zastąpienia, stanowią konstrukcję składającą się z tzw. poszycia, łączników i elementów nośnych, podpierających oraz wsporników. Deskowania, rozumiane jako specyficzny rodzaj konstrukcji tymczasowej, są używane do realizacji budowli betonowych lub żelbetowych. Ich zadaniem jest nadanie oczekiwanego, zgodnego z projektem architektonicznym i konstrukcyjnym kształtu mieszance betonowej oraz utrzymaniu właściwego ułożenia zbrojenia podczas betonowania, aż do chwili zakończenia okresu twardnienia mieszanki betonowej i uzyskania przez beton odpowiedniego poziomu wytrzymałości na ściskanie (ORŁOWSKI Z. 2013).

Wprowadzenie na rynek budowlany urządzeń formujących miało na celu usprawnienie realizacji konstrukcji betonowych, dzięki czemu formowanie monolitycznych elementów betonowych stało się dużo łatwiejsze i szybsze. Kolejnym krokiem rozwoju technologii betonu monolitycznego było wykorzystanie alternatywnych urządzeń formujących tzw. deskowania traconego, stanowiącego odrębną kategorię deskowań budowlanych (JASICZAK J. 2003, WESOŁOWSKA M., SZCZEPANIAK P. 2012).

Niniejszy rozdział został poświęcony zagadnieniom związanym z ówcześnie stosowanymi traconymi urządzeniami formującymi.

\section{Deskowania tracone}

Deskowanie tracone jest jednym $\mathrm{z}$ systemów deskowań stosowanych w technologii monolitycznego budownictwa betonowego. Urządzenie formujące tego typu jest elementem nierozbieralnym, dlatego też często nazywane jest deskowaniem wbudowanym. Zatem po ukończeniu prac betoniarskich stanowi ono nieodzowną część konstrukcji. Na etapie realizacji obiektu czy elementu betonowego pełni funkcję formująco-podtrzymującą, natomiast w okresie eksploatacyjnym owe deskowanie stanowi część konstrukcyjną obiektu, izolacyjną lub pełni obie te funkcje jednocześnie (JASICZAK J. 2003).

Technologia deskowań traconych cechuje się małą pracochłonnością oraz krótkim czasem montażu. Rozwój tego tupu urządzeń formujących wiąże się ze stosunkowo niskimi kosztami nakładu oraz możliwością zastosowania coraz to nowszych, bardziej ergonomicznych rozwiązań konstrukcyjno-materiałowych, w tym wbudowywanie materiałów proekologicznych, o znacznie niższej przewodności cieplnej i wysokiej izolacyjności. Poszczególne elementy deskowań traconych na 
miejsce montażu zwykle dostarczane są w formie dyli zasypowych, ale również wielkowymiarowych deskowań przestrzennych (KORONA L. 2011).

\subsection{Klasyfikacja deskowań traconych}

Szeroki wybór rozwiązań technologicznych systemów deskowań traconych umożliwia ich klasyfikację. Współczesne deskowania tracone można podzielić zasadniczo na trzy grupy. Jeden z kryteriów podziału deskowań jest zależny od rodzaju konstrukcji do której deskowanie zostało zastosowane. Pozostałe dwa kryteria uzależnione są od funkcji poszycia deskowania oraz sposobu ich użytkowania (tzn. od kierunku oddziaływania obciążeń). Schemat klasyfikacji deskowań traconych przedstawiono na rys. 1. (JASICZAK J. 2003, KORONA L. 2011).

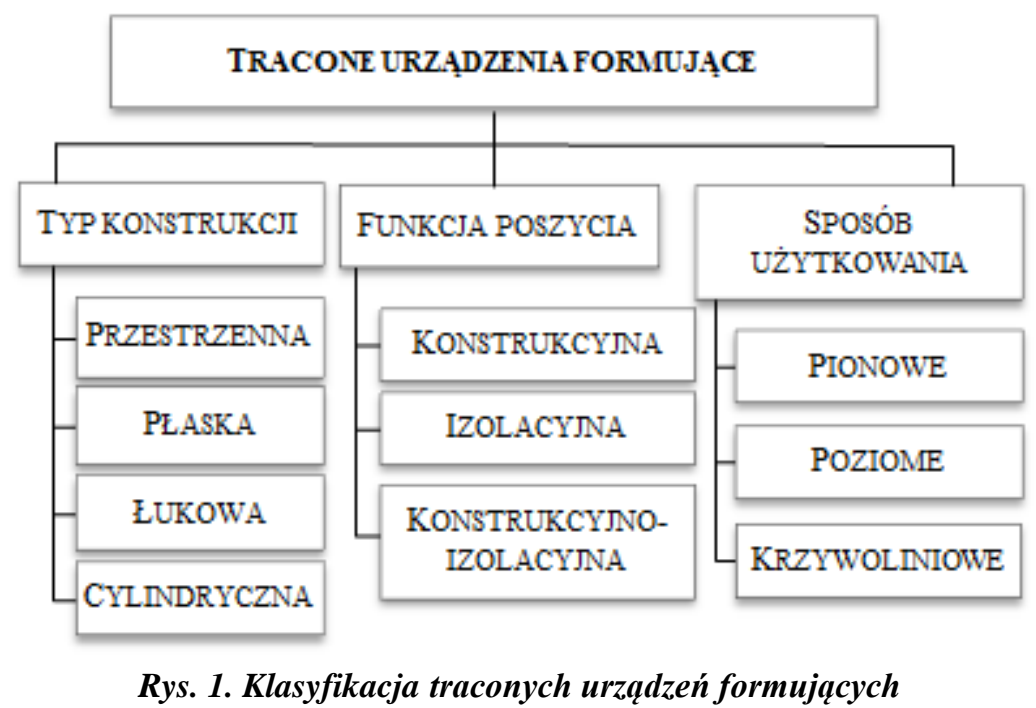

Źródto: KORONA L. 2011

\subsection{Wymagania dotyczące deskowań}

Podstawowymi zadaniami deskowania, montowanego zarówno tymczasowo jak i na stałe, jest zapewnienie wymaganego kształtu formowanego elementu aż do chwili uzyskania jego samonośności, a także zapewnienie zachowania konstrukcji zgodnego z założonym modelem projektowym. Betonowe elementy konstrukcji niejednokrotnie stanowią podstawowy element konstrukcyjny lub współpracują z innymi ustrojami konstrukcyjnymi. Zatem zapewnienie właściwej pracy monolitycznych konstrukcji betonowych czy żelbetowych według założonego schematu statycznego jest warunkiem koniecznym do spełnienia (BAJOREK G., SŁONINA S. 2017). 
W trakcie układania mieszanki betonowej na urządzenia formujące oddziałuje szereg sił zewnętrznych. W zaleceniach projektowych dotyczących warunków wykonania i ogólnych zasad projektowania deskowań budowalnych zawartych w aktualnej normie europejskiej (PN-EN 12812: 2008), wiodącym parametrem projektowym odnoszącym się do konstrukcji deskowań jest parcie mieszanki betonowej (SZRUBA M. 2016). W elementach pionowych rośnie ono liniowo w momencie kiedy mieszanka betonowa jest płynna, natomiast $\mathrm{w}$ chwili rozpoczęcia procesu wiązania betonu - rozkłada się równomiernie na całej wysokości deskowania. Ponadto należy zwrócić uwagę, iż stosowanie plastyfikatorów oraz domieszek opóźniających wiązanie mieszanki betonowej powoduje zwiększenie wartości parcia bocznego (JASICZAK J. 2003). Tracone urządzenia formujące są szczególnym rodzajem konstrukcji tymczasowej, ponieważ są one trwale związane z formowanym elementem. Nadają nie tylko wymagany kształt, sztywność oraz nośność betonowanych elementów aż do chwili związania, ale dodatkowo zapewniają właściwości wspomagające, takie jak izolacyjność termiczna czy przeciwwilgociowa, a nawet mogą przyczynić się do zwiększenia nośności gotowego elementu konstrukcyjnego (ORŁOWSKI Z. 2013).

\section{Wybrane systemy deskowań traconych}

Wybór odpowiedniego systemu deskowań ma znaczący wpływ zarówno na jakość techniczną konstrukcji realizowanej w technologii betonu, jak i na wydajność wykonywanych robót budowlanych. Właściwy dobór systemu deskowań może w znaczny sposób przyczynić się do usprawnienia całego procesu inwestycyjnego, a nawet może prowadzić do zmniejszenia kosztów realizacji. Odpowiedniego doboru deskowania można dokonać zwracając szczególną uwagę na aspekty (IBADOV N., KACZOREK K. 2014):

- techniczne (określenie nośności deskowania, ciężaru własnego),

- organizacyjne (zwrócenie uwagi na logistykę budowy, lokalizację na teren budowy, pory roku realizacji inwestycji),

- ekonomiczne (oszacowanie kosztów robocizny oraz zakupu),

- ekologiczne (analiza wpływu na środowisko, możliwości recyklingu).

Obecnie producenci deskowań modyfikują oferty dostosowując je do potrzeb rynku tak, aby były łatwe w budowie oraz szybkie w montażu (SzRUBA M. 2016). Również w zakresie deskowań traconych wybór urządzeń formujących jest coraz szerszy. 


\subsection{System Concrete Form}

Deskowania tracone mające po zakończeniu procesu wiązania betonu pełnić funkcje izolacyjną głównie stosuje się przy realizacji ścian zewnętrznych. Obecnie w wielu krajach stosowane są różnorodne metody realizowania monolitycznych konstrukcji betonowych przy użyciu deskowania będącego jednocześnie warstwą ciepłochronną ściany. Jedną z metod jest system deskowań traconych CF (Concrete Form). System składa się z dwóch równoległych płaszczyzn płyt styropianowych typu M30 lub płyt styrodurowych, połączonych ze sobą łącznikiem z tworzywa sztucznego. Współczynnik przenikania ciepła ściany wypełnionej betonem zwykłym, przy założonej grubości ocieplenia równiej $0,20 \mathrm{~m}$ może wynosić $0,21 \mathrm{~W} / \mathrm{m}^{2} \mathrm{~K}$ (JASICZAK J. 2003).

Deskowania tracone pełniące funkcję izolacji są doskonałą alternatywą stosowaną przy realizacji ścian dwuwarstwowych zewnętrznych $\mathrm{w}$ budynkach energooszczędnych. Urządzenia formujące tego typu tworzą formę gotową do wykonania betonowego elementu mającego pełnić funkcję nośną budynku. Obecnie najpowszechniej stosowane są rozwiązania polegające na zastosowaniu technologii deskowań traconych wykorzystujących płyty cementowo-drzazgowe oraz izolacyjne kształtki styropianowe. Charakterystyka energetyczna dla tego typu rozwiązań materiałowych świadczy o możliwości uzyskania oszczędności zapotrzebowania na energię końcową do ogrzewania o ponad 30\% w stosunku do rozwiązania referencyjnego, spełniającego wymagania w zakresie izolacyjności termicznej (WeSOŁOWSKA M., SZCZEPANIK P. 2016). Do nieco nowszych rozwiązań systemów deskowań traconych pełniących funkcję izolacji można zaliczyć system Isoteq, gdzie do produkcji kształtek wykorzystuje się materiał Neopor. Dzięki dodaniu grafitu do tworzywa styropianowego podczas procesu technologicznego posiada on lepsze właściwości izolacyjne niż styropian. System Isoteq (rys. 2.) wykorzystywany jest również do realizacji domów energooszczędnych lub pasywnych. W zależności od oczekiwanej energooszczędności, współczynnik przewodności cieplnej ścian wykonanych w tym systemie wynosi $0,11-0,18 \mathrm{~W} / \mathrm{m}^{2} \mathrm{~K}$ (KORONA L. 2011). 


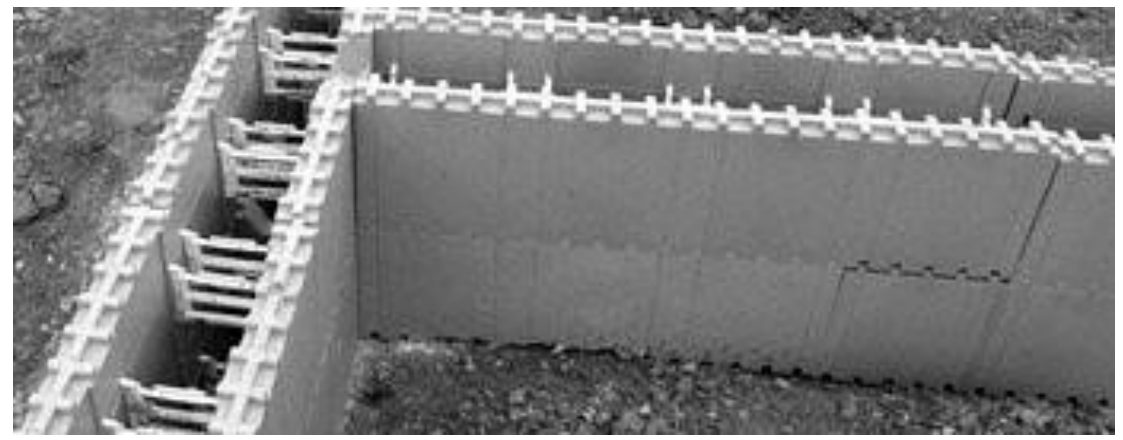

Rys. 2. System Isoteq stosowany do produkcji ścian w budownictwie energooszczędnym i pasywnym

Źródto: http://isoteq.eu/plinth/

\subsection{System deskowania uniwersalnego}

Obecnie na rynku budowlanym dostępne są również deskowania uniwersalne, które mogą pełnić funkcję zarówno deskowania wielokrotnego użytku, jak i deskowania traconego. Przykładem jest system deskowania Pecafil. System ten składa się elementów poszycia wykonanego z siatki stalowej, które dodatkowo są dwustronnie pokryte specjalną folią polietylenową (KORONA L. 2011). Dodatkowo system Pecafil nie wymaga stosowania środków antyadhezyjnych do betonu, ponieważ folia wykonana jest $\mathrm{z}$ czystych węglowodorów łańcuchowych, zbliżonych strukturą do używanej $\mathrm{w}$ produkcji świec parafiny. Ponadto polietylen należy do odpadów obojętnych, które nie wydzielają szkodliwych substancji do ziemi, wody gruntowej czy powietrza. Tego typu urządzenia formujące pozostawione w gruncie nie narażają środowiska na zanieczyszczenie.

Dodatkowym atutem uniwersalnego systemu deskowania Pecafil jest łatwy montaż, dzięki lekkości elementów składowych i możliwości ich prostego kształtowania i formowania. Jest to rozwiązanie ekonomiczne dzięki czemu szeroki zakres stosowania umożliwi wykonywanie deskowania m.in.:

- ścian o złożonych kształtach,

- fundamentów (rys. 3a), w tym również wzmocnionych,

- pali wierconych (rys. 3b),

- stropów kasetonowych (rys. 4a) oraz żebrowych (rys. 4b). 
a)

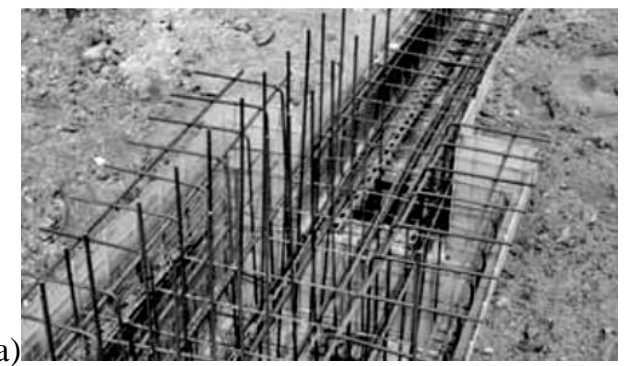

b)

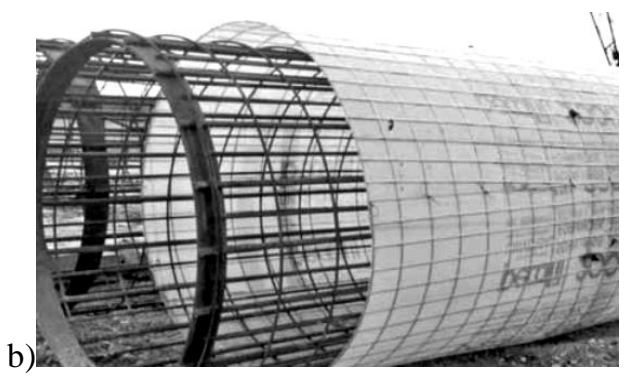

Rys. 3. System Pecafil stosowany jako deskowanie: a) fundamentów, b) pali

Źródto: http://www.maxfrank.com/media/dokumente/produkte/pl/broschueren/Frank-KT-Pecafil-systemlekkich-szalunkow-pl.pdf

a)
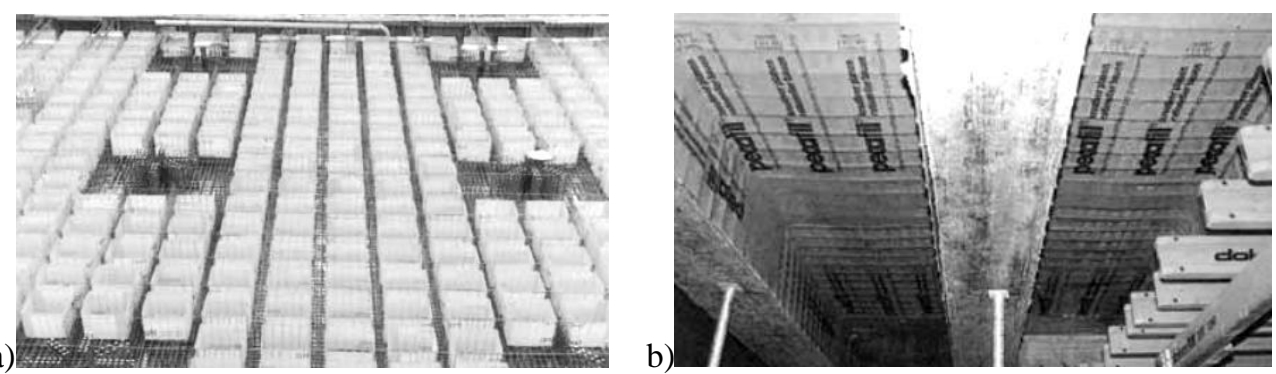

\section{Rys. 4. System Pecafil stosowany jako deskowanie stropów: a) kasetonowych, b) żebrowych} Źródto: http://www.maxfrank.com/media/dokumente/produkte/pl/broschueren/Frank-KT-Pecafil-systemlekkich-szalunkow-pl.pdf

\subsection{Kompozytowe deskowanie tracone}

Współczesny rozwój materiałów kompozytowych stwarza możliwości ich zastosowania niemal we wszystkich sektorach budownictwa. Tego typu materiały (mikrokompozyty, nanokompozyty) odnajdują swoje zastosowanie również jako urządzenia formujące. Do najpowszechniej stosowanych materiałów kompozytowych w dziedzinie budownictwa należą kompozyty FRP (Fiber Reinforced Polymer) zbrojone włóknem (SELEJDAK J., BRÓZDA K. 2016):

- szklanym (GFRP - Glass Fiber Reinforced Polymer),

- węglowym (CFRP - Carbon Fiber Reinforced Polymer),

- bazaltowym (BFRP - Basalt Fiber Reinforced Polymer),

- $\quad$ aramidowym (AFRP - Aramid Fiber Reinforced Polymer).

Nowym trendem w technologii deskowań traconych jest stosowanie kompozytów takich jak włóknobetony czy siatkobetony, wykorzystujące jako 
komponent konstrukcyjny włókna sztuczne. Jednakże swoje zastosowanie, zwłaszcza w deskowaniach dla budownictwa niskiego, odnajdują kompozyty wykonane na bazie włókien naturalnych, pozyskiwanych z materiałów organicznych (BRÓzDA K. 2015), ale również pozyskiwane $\mathrm{z}$ odpadów lub jako produkty uboczne tj. styrobeton, trzcinobeton, wióro- i drzazgocement czy komponent magnezytowo-drzazgowy. Dodatkowo celem zwiększenia właściwości izolacyjnych deskowania traconego dodaje się np. perlit, dzięki czemu współczesne deskowania wykonane są z materiałów bioodpornych, niepalnych oraz nietoksycznych (KORONA L. 2011).

W ostatnich latach prowadzone są badania dotyczące zastosowania profili kompozytowych GFRP jako nowego systemu deskowań traconych. Profile kompozytowe GFRP stanowią nie tylko deskowanie płyty betonowej, które nie zostaje usunięte po zakończeniu procesu wiązania betonu, ale również stanowią część konstrukcyjną płyty. Dodatkową zaletą tego systemu jest wykorzystanie wysokiej wytrzymałości na korozję materiału kompozytowego, który chroni metalowe pręty zbrojeniowe płyty przed działaniem agresywnych czynników środowiska. Nośność elementu, tzn. kompozytowego profilu GFRP zespolonego z żelbetową płytą, jest zależna $\mathrm{w}$ dużej mierze od warunków przyczepności na powierzchni styku betonukompozyt i zwiększa się wraz ze wzrostem tejże przyczepności (KOTEŠ P., VIČAN J. 2010). Schemat przekroju poprzecznego kompozytowego systemu deskowania traconego został przedstawiony na rys. 5 .

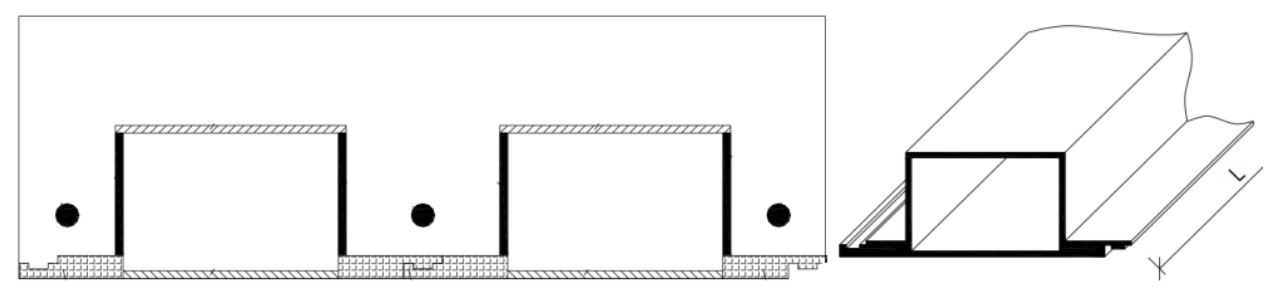

Rys. 5. Schemat przekroju poprzecznego deskowania traconego GFRP

Źródto: KOTEŠ P., VIČAN J. 2014

W badaniach udowodniono, iż przy tego typu rozwiązaniu technologicznym, dzięki użytym profilom GFRP można uzyskać mniejsze wartości wysokości całkowitej badanej płyty przy zachowaniu właściwej nośności elementu. Oznacza to oszczędności związane z mniejszym zużyciem materiału tj. betonu oraz stali zbrojeniowej (KOTEŠ P., VIČAN J. 2010). 


\section{Podsumowanie}

Duże zainteresowanie technologią betonu monolitycznego przyczynia się do rozwoju rozmaitych systemów specjalnych urządzeń formujących, tj. deskowań budowlanych, które są elementem niezbędnym w czasie procesu realizacji konstrukcji betonowych. Jednym ze szczególnych rodzajów tego typu urządzeń jest deskowanie tracone, pełniące nie tylko funkcję formującą, ale stanowiące część konstrukcji również w okresie eksploatacyjnym obiektu. Podczas projektowania deskowań traconych należy pamiętać nie tylko o obciążeniach jakie mają przenosić w fazie realizacji. Konieczne jest zwrócenie uwagi na funkcję jaką mają pełnić również w fazie eksploatacji.

Wybór właściwego systemu deskowania jest niezwykle ważnym aspektem, zwłaszcza jeżeli ma być ono wbudowane na stałe i stanowić część konstrukcji. Deskowania tracone wykorzystuje się coraz częściej do realizacji indywidualnie projektowanych obiektów specjalistycznych, a połączenie technologii monolitycznej z prefabrykowaną zmniejsza koszt i czas realizowanej inwestycji budowlanej. Rozwój rozwiązań konstrukcyjno-materiałowych umożliwia podniesienie jakości wykonywanych robót budowlanych jak i samej konstrukcji. Przykładowo zastosowanie deskowania traconego pełniącego funkcję izolacyjną do budowy domów energooszczędnych zmniejsza koszty późniejszego utrzymania obiektu, poprzez zmniejszenie wartości wskaźnika energii końcowej świadczącego o wysokiej jakości wykonanego budynku. Z kolei deskowania tracone, wykonane z kompozytowych profili pełniących funkcję konstrukcyjną, może przyczynić się do wzrostu nośności wykonanego elementu betonowego lub pozwolić na zmniejszenie jego wymiarów przekroju poprzecznego bez utraty oczekiwanej nośności. Ponadto współczesne deskowania tracone wykonuje się również $\mathrm{z}$ materiałów biodegradowalnych i bezodpadowych, np. zbliżonych swoją strukturą do nieagresywnej w stosunku do środowiska parafiny. Te innowacyjne rozwiązania materiałowe oraz nowoczesne techniki wykonania powodują wśród inwestorów wzrost zainteresowania technologią deskowań traconych, które tworzą bardzo specyficzną grupę konstrukcji tymczasowych.

\section{Bibliografia}

1. BAJOREK G., SŁONINA S. 2017. Odbiór deskowań do wykonywania konstrukcji z betonu na co zwrócić szczególna uwagę. „Inżynier Budownictwa” 4/2017.

2. BRÓZDA K. 2015. Ekologiczne materiały kompozytowe $w$ budownictwie. Rozdział 5. W/In: Ekoinnowacje w materiałach i technologiach budowlanych. Ulewicz, M., Selejdak, 
J. (red.) Wydawnictwo Wydziału Zarządzania Politechniki Częstochowskiej. Częstochowa.

3. IbAdov N., KaczoreK K. 2014. Projektowanie technologiczne oraz dobór deskowań stosowanych $w$ budownictwie inżynieryjnym na przykladzie budownictwa mostowego. „Inżynier Budownictwa” 5/2014.

4. IGNATOWSKI P. 2008. Realizacja żelbetowych konstrukcji nowoczesnych budynków użyteczności publicznej. „Materiały Budowlane” 6/2008.

5. JASICZAK J. 2003. Technologie budowlane II. Politechnika Poznańska, Wydział Budownictwa, Architektury i Inżynierii Środowiska, Instytut Konstrukcji Budowlanych. Poznań.

6. KORONA L. 2011. Innowacyjne technologie deskowań traconych. „Civil and Environmental Engineering" 2/2011.

7. KоTEŠ P., VIČAN J. 2010. Stay-in-place GFRP formwork. Third International fib Congress incorporating the PCI Annual Convention and Bridge Conference 2010. Volume 1 of 6. Washington.

8. KоTEŠ P., VIČAN J. 2014. Using stay-in-place GFRP formwork and concrete slab as hybrid composite structure. The $7^{\text {th }}$ International Conference on FRP Composites in Civil Engineering. Vancouver.

9. ORŁowsKi Z. 2013. Podstawy technologii betonowego budownictwa monolitycznego. Wydawnictwo Naukowe PWN. Warszawa.

10. PN-EN 12812: 2008. Deskowanie. Warunki wykonania i ogólne zasady projektowania.

11. PN-M-47850: 1990. Deskowania dla budownictwa monolitycznego. Deskowania uniwersalne. Terminologia, podziat i główne elementy składowe.

12. SELEJDAK J., BRÓzDA K. 2016. Zastosowanie kompozytów w budownictwie zrównoważonym. Rozdział 9. W/In: Zagadnienia inżynierii środowiska w budownictwie. Rak, A., Boychuk, V., Baran, W. (red.) Wyd. Polski Związek Inżynierów i Techników Budownictwa, Oddział w Opolu. Opole.

13. SzRuBA M. 2016. Deskowania i rusztowania. „Nowoczesne Budownictwo Inżynieryjne” $3-4 / 2016$.

14. Wesolowska M., SzCZEPANiAK P. 2016. Technologia deskowań traconych w budynkach energooszczędnych. „Izolacje” 3/2016. 